\title{
Erratum
}

\section{Erratum to "Health Brokers: How Can They Help Deal with the Wickedness of Public Health Problems?"}

\author{
Celeste E. van Rinsum ${ }^{D}$, ${ }^{1}$ Sanne M. P. L. Gerards, ${ }^{1}$ Geert M. Rutten, ${ }^{1}$ \\ Ien A. M. van de Goor, ${ }^{2}$ and Stef P. J. Kremers ${ }^{1}$ \\ ${ }^{1}$ Department of Health Promotion, NUTRIM School for Nutrition and Translational Research in Metabolism, \\ Maastricht University, P.O. Box 616, 6200 MD Maastricht, Netherlands \\ ${ }^{2}$ Department Tranzo, Tilburg School of Social and Behavioral Sciences, Tilburg University, P.O. Box 90153, \\ 5000 LE Tilburg, Netherlands \\ Correspondence should be addressed to Celeste E. van Rinsum; celeste.vanrinsum@maastrichtuniversity.nl
} Received 26 December 2017; Accepted 3 January 2018; Published 21 February 2018

Copyright (c) 2018 Celeste E. van Rinsum et al. This is an open access article distributed under the Creative Commons Attribution License, which permits unrestricted use, distribution, and reproduction in any medium, provided the original work is properly cited.

In the article titled "Health Brokers: How Can They Help Deal with the Wickedness of Public Health Problems?" [1], reference 35 was incorrectly included as Loketgezondleven.nl. Decentralisatie en lokaal bestuur in Ghana, AGORA Magazine, 2016, 32(1) (doi: 10.21825/agora.v32i1.3654) https:// www.loketgezondleven.nl/gezonde-gemeente/gezondheidsbeleid-maken/wettelijke-kaders-gezondheidsbeleid/decentralisatie, while it should be corrected as Loketgezondleven.nl, Decentralisatie overheidstaken (Decentralisation government tasks), 2016, https://www.loketgezondleven.nl/gezonde-gemeente/gezondheidsbeleid-maken/wettelijk-en-beleidskader-publieke-gezondheid/decentralisaties. It has been corrected in place too.

\section{References}

[1] C. E. van Rinsum, S. M. P. L. Gerards, G. M. Rutten, I. A. M. van de Goor, and S. P. J. Kremers, "Health brokers: how can they help deal with the wickedness of public health problems?" BioMed Research International, vol. 2017, Article ID 1979153, 10 pages, 2017. 


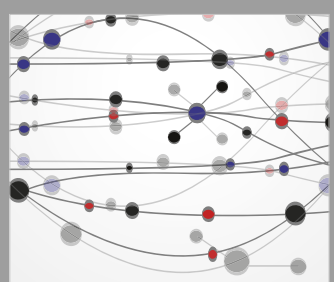

The Scientific World Journal
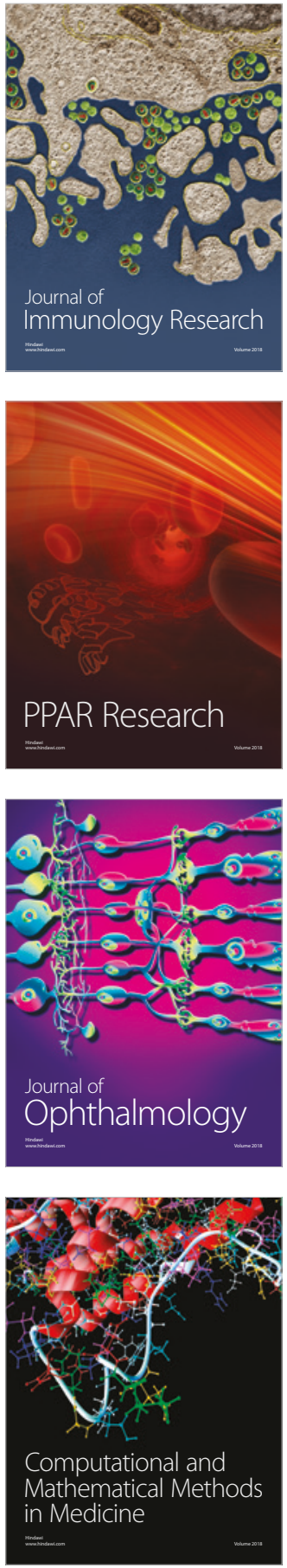

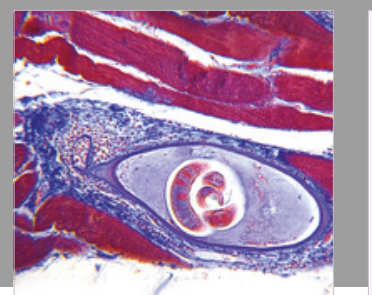

Gastroenterology Research and Practice

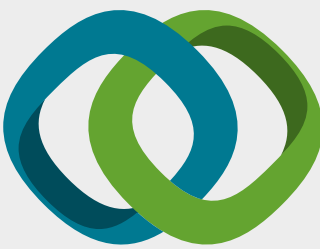

\section{Hindawi}

Submit your manuscripts at

www.hindawi.com
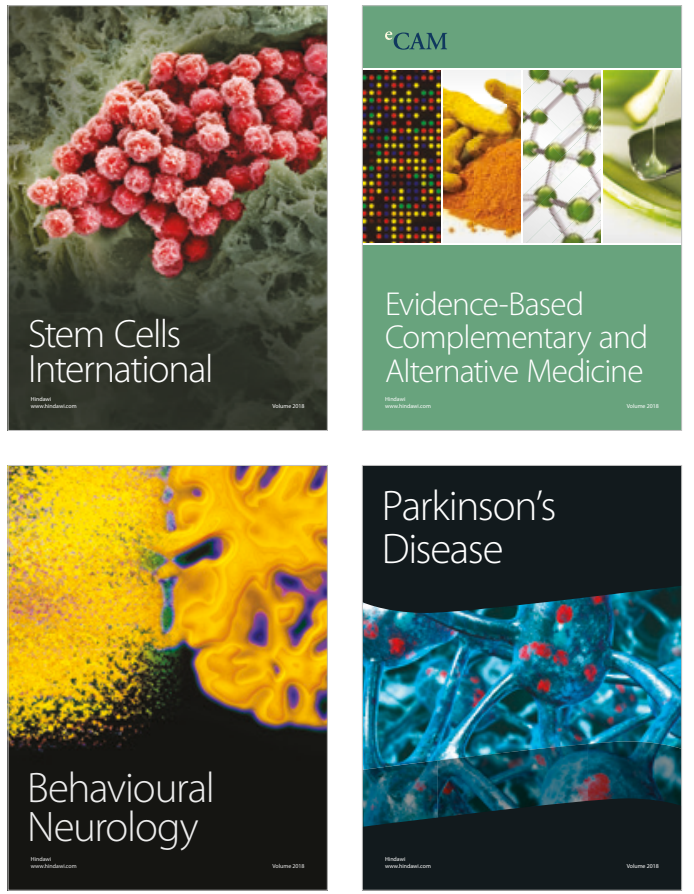

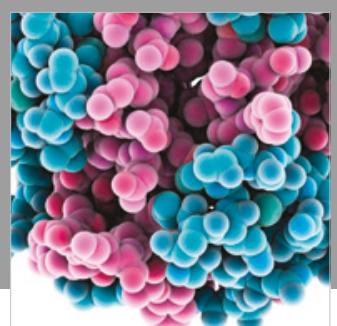

ournal of

Diabetes Research

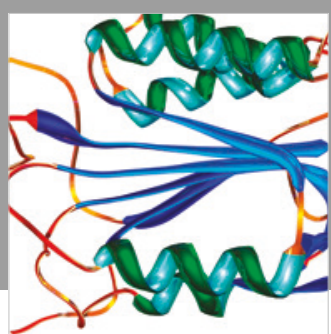

Disease Markers
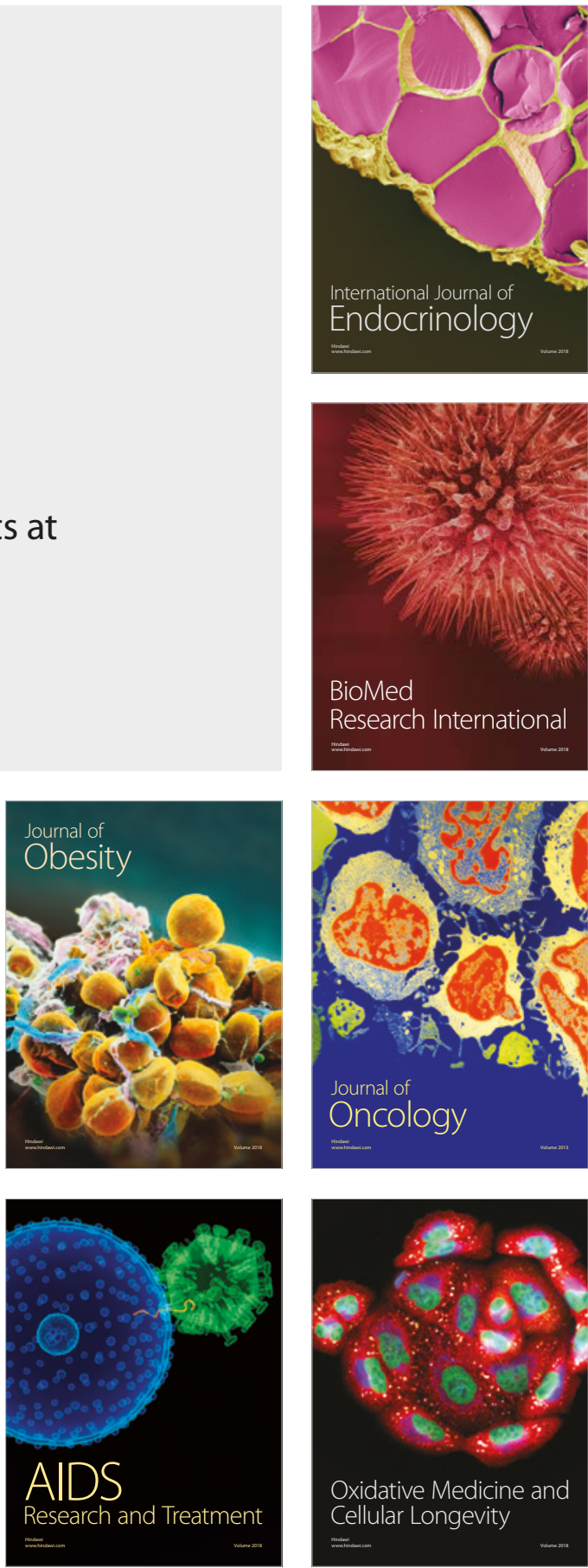